\title{
Daily activity patterns of ungulates at water holes during the dry season in the Waterberg National Park, Namibia
}

\author{
Evert Kasiringua, Grzegorz Kopij* \& Şerban Procheş
}

\begin{abstract}
In this study, daily drinking activity of all 12 herbivore species were conducted in the dry season at seven waterholes in the Waterberg National Park, Namibia, where only leopard Panthera pardus was present as a large carnivore. Drinking was more frequent between $15 \mathrm{~h} 00$ and $22 \mathrm{~h} 00$ than in the rest of the day. A conspicuous peak in drinking activity was in the evening between $18 \mathrm{~h} 00$ and $19 \mathrm{~h} 00$, when $15 \%$ of animals were recorded drinking water. Water holes had various frequency of attendance by particular ungulate species. Eland Tragelaphus oryx and buffalo Syncerus caffer were most frequently recorded species at water holes, comprising together almost half of all ungulates recorded. The kudu Tragelaphus strepsiceros, roan Hippotragus equinus, sable antelope Hippotragus niger and warthog Phacochoerus africanus were also in the group of water-dependent species (comprising together at water holes $41.2 \%$ of all animals recorded). Four groups of ungulates may be distinguished in the Waterberg National Park based on their daily drinking activity patterns: 1) evening and night drinkers: white rhino Ceratotherium simum, black rhino Diceros bicornis and buffalo (i.e., those free of leopard predation risk); 2) night and morning drinkers: eland, gemsbok Oryx gazella and kudu (i.e. those with limited leopard predation risk); 3) day drinkers: warthog, giraffe Giraffa camelopardalis, roan, sable antelope, red hartebeest Alcephalus buselaphus (high leopard predation risk); 4) whole day and night drinkers: dik-dik Madoqua kirkii, steenbok Raphicerus campestris, common duiker Sylvicapra grimmia. Most animals drinking during the night were more active in the first half (18h00-24h00) than in the second half (24h00-6h00) of the night.

How to cite this article: Kasiringua E., Kopij G., Procheş Ş. 2017. Daily activity patterns of ungulates at water holes during the dry season in the Waterberg National Park, Namibia // Russian J. Theriol. Vol.16. No.2. P.129-138. doi: 10.15298/rusjtheriol.16.2.02
\end{abstract}

KEY WORDS: African ungulates, behaviour, daily activity, wildlife management.

Evert Kasiringua, Discipline of Geography, University of KwaZulu-Natal, Westville Campus, PB X54001, Durban 4000, South Africa; Department of Integrated Environmental Science, University of Namibia, Ogongo Campus, Private Bag 5520 Oshakati, Namibia; Grzegorz Kopij [gkopij@unam.na], Department of Integrated Environmental Science, University of Namibia, Ogongo Campus, Private Bag 5520 Oshakati, Namibia; Şerban Procheş, Discipline of Geography, University of KwaZulu-Natal, Westville Campus, PB X54001, Durban 4000, South Africa.

\section{Суточная активность копытных вблизи водоемов в сухой сезон в Национальном парке Ватерберг, Намибия}

\section{Э. Касирингуа, Г. Копий*, щ. Прокеш}

РЕЗЮМЕ. Исследована суточная активность 12 видов травоядных животных в сухой сезон у семи источников воды в Национальном парке Ватерберг, Намибия, где присутствует лишь один крупный хищник - леопард Panthera pardus. Питье было отмечено в период между 15:00 и 22:00 чаще, чем в остальное время суток. Заметный пик активности питья был вечером между 18:00 и 19:00, когда было отмечено 15\% животных, пьющих воду. Частота посещения водопоев отдельными видами была различна. Наиболее часто у водопоев были отмечены канна Tragelaphus oryx и буйвол Syncerus caffer, составляя вместе почти половину всех зарегистрированных копытных.

В группу зависящих от наличия воды видов также входят куду Tragelaphus strepsiceros, лошадиная антилопа Hippotragus equinus, черная антилопа Hippotragus niger и бородавочник Phacochoerus africanus (вместе они составляют 41.2\% всех зарегистрированных у водопоев животных). Среди копытных Национального парка Ватерберг можно выделить 4 группы по типу суточной активности на водопоях: 1) вечерние и ночные посетители: белый носорог Ceratotherium simum, черный носорог Diceros bicornis и буйвол (риск нападения леопарда отсутствует); 2) ночные и вечерние посетители: канна, орикс Oryx gazella и куду (риск нападения леопарда ограничен); 3) дневные посетители: бородавочник, жираф Giraffa camelopardalis, лошадиная антилопа, черная антилопа, конгони Alcephalus buselaphus (риск нападения леопарда высок); 4) пьющих воду в течение всего

* Corresponding author 
дня и ночи: дикдик Madoqua kirkii, стенбок Raphicerus campestris, обыкновенный дукер Sylvicapra grimmia. Большинство животных, которые пили в течение ночи, были более активными в первой половине (18:00-24:00), чем во второй половине (24:00-06:00) ночи.

КЛЮЧЕВЫЕ СЛОВА: африканские копытные, поведение, суточная активность, природопользование.

\section{Introduction}

Daily activity patterns are an important feature of biology of any animal species. They are affected by feeding and drinking, temperature and humidity, predators and competitors, biological cycle, moon phases and other minor factors (Aschoff, 1964; Wakefield \& Attum, 2006; Hayward \& Hayward, 2012; Kanda \& Cote, 2012). In Africa, water requirement and its availability may greatly affect the daily activity pattern of some animals. Effective management depends on the knowledge of such patterns (Winterbach \& Bothma, 1998). This is especially applicable to larger ungulates (they have high economic value and high water requirements), such as elephant Loxodonta africana, white rhino Ceratotherium simum, black rhino Diceros bicornis, plain zebra Equus quagga, giraffe Giraffa camelopardalis, buffalo Syncerus caffer, eland Tragelaphus oryx, gemsbok Oryx gazella, kudu Tragelaphus strepsiceros, blue wildebeest Connochaetes taurinus and red hartebeest Alcephalus buselaphus. Their general daily activity rhythm consists of alternating bouts of grazing and resting/ruminating (Winterbach \& Bothma, 1998). Drinking occupies merely a few percent of their daily activity budget (Rayn \& Jordaan, 2005) and is often not even considered in budget calculations (e.g. Winterbach \& Bothma, 1998; du Toit \& Yetman, 2005; Regassa, 2014; Tahani \& Ibrahim, 2014; Tekaling \& Bekele, 2015). It is, however, one of the most essential activities in their life affecting all aspects of their biology, ecology and conservation (Hayward \& Hayward, 2012).

To date, studies on daily activity of African ungulates at water holes were conducted in the Hwange National Park, Zimbabwe (Weir \& Davisen, 1960; Crosmary et al., 2012), Amboseli N. P., Kenya (Western, 1975), Etosha N. P., Namibia (du Preez \& Grobler, 1977), and in Kruger N. P., South Africa (Thrash, 1998; Cain et al., 2012; Hayward \& Hayward, 2012).

The aim of this study was to investigate the daily drinking activity pattern of ungulates in another important African conservation area, the Waterberg National Park (WNP) in Namibia. Drinking is a highly risky activity, as large predators tend to focus attention around major water holes (Crosmary et al., 2012). In order to avoid being preyed upon, ungulates should develop such activity patterns that enable them to minimize the predation risk (for example by avoiding nights when predators are most active). On the other hand, ungulates will also compete among themselves for a free access to water (especially during the day). It may be expected, therefore, that the larger ungulate species, as those less vulnerable to predation, should be more nocturnal in their drinking activity than the smaller species, more vulnerable to predation. Species of medium size should show no special preference in that regard. In this study, we test this hypothesis.

\section{Study area}

WNP is situated in the Otjozonjupa Region in northern Namibia, $280 \mathrm{~km}$ N of Windhoek and $68 \mathrm{~km} \mathrm{SE}$ of Otjiwarongo, at the following coordinates: $20^{\circ} 25^{\prime} \mathrm{S}$, $17^{\circ} 13^{\prime} \mathrm{E}$ (Fig. 1). WNP is $49 \mathrm{~km}$ long from SW to NE, and $8-16 \mathrm{~km}$ width. It is 40500 ha in surface size, with 40000 ha on the plateau and 500 ha in foothills.

The plateau arises from 1550 to $1850 \mathrm{~m}$ above sea level and between 100 to $300 \mathrm{~m}$ above the surrounding bush plains. The periphery of the plateau forms almost a vertical cliff, up to $300 \mathrm{~m}$ high. The top of the plateau is made up of aeolianite (lithified dunes) of the Etjo Formation, which is ca. 200 million years old. The sandstone is covered with Kalahari sand (W. Hegenberger, unpubl. report). There are no permanent water courses or pans. The water is pumped into seven drinking holes (Fig. 1, Table 1), so it is freely available throughout the year.

The vegetation falls into the broad-leaf woodlands which are typical of the sandveld of eastern and northeastern parts of Namibia (Mendelsohn et al., 2009). Three main vegetation communities within this type have been recognized: Terminalia sericea-Molhania acuminata, Terminalia sericea-Blepharis integrifolia, Terminalia sericea-Thesium megalocarpum, and Peltophorum africanum rock community (Jankowitz, 1983).

Over 500 flowering plants and 140 lichen species were recorded in the WNP. Common trees include Acacia ataxacantha, Burkea africana, Combretum collinum, C. psidioides, Dichrostachys cinerea, Grewia flavescens and G. retinervis, Lonchocarpus nelsii, Ochna pulchra, Peltophorum africanum, Terminalia sericea and Ziziphus mucronata. Common grass species are Andropogon schirensis, Brachiaria nigropedata, Digitaria seriata, Eragrostis jeffreysii, E. pallens, E. rigidior and Panicum kalaharense (Jankowitz \& Venter, 1987; Mendelsohn et al., 2009).

The plateau is divided into six burning blocks, each of which is burnt every 6-8 years. WNP falls into the 'Hot Steppe' climatic zone. The mean temperature is above $18^{\circ} \mathrm{C}$. More than $90 \%$ of the rainfall occurs from October to March. Average annual rainfall at Onjoka (below the Plateau) is $450.2 \pm 75.4 \mathrm{~mm}$ (Mendelsohn et al., 2009). The monthly variation of rainfall in the years of study is shown in Fig. 2. 




Fig. 1. Location of the study area and distribution of waterholes (1-7) in the Waterberg National Park.

Among large carnivores, only leopard Panthera pardus is present in WNP. It reaches a density of 1 individual per $100 \mathrm{~km}^{2}$ (Stein et al., 2011). This is rather low in comparison with 3.6 individuals per $100 \mathrm{~km}^{2}$ in the neighbouring farms (Stein et al., 2011), but higher than in Etosha National Park (Stander et al., 1997). Other carnivore species, such as the cheetah Acinonyx jubatus, spotted hyaena Crocuta crocuta or hunting dog Lycaon pictus appear in WNP only occasionally.

\section{Methods}

Studies were conducted at seven waterholes in the WNP (Fig. 1, Table 1). Observations were conducted from specially constructed wooden shelter situated in a close proximity (ca. $50 \mathrm{~m}$ ) to the water hole. Observa- tions were carried out in the peak of the dry season, when the ungulates usually concentrate near water holes. The counts were organized around full moon nights to achieve greater visibility of the game during the night. Observations were aided with binoculars.

Counts were conducted by a team of 2-4 observers, three times in dry season: June 1991, August 1992 and July 2012. At each water point, 2-3 observers counted animals visiting the waterholes for 48 hours, i.e. from $10 \mathrm{~h} 00$ to $10 \mathrm{~h} 00$ of the second following day in June 1991 and August 1992, and from 6h00 to 6h00 of the first following day in July 2012.

Each animals coming for drinking was timed, counted and identified to species level. Whenever possible, each individual was also sexed and aged, and identified individually (especially rhinos and giraffe) as to avoid double counting of some individuals which come more

Table 1. Location and elevation of the waterholes on the Waterberg National Park.

\begin{tabular}{|l|c|c|c|}
\hline Water-Holes & Coordinates longit. & Coordinates latit. & Elevation \\
\hline Bergtuin & $20^{\circ} 22^{\prime} 45^{\prime \prime} \mathrm{S}$ & $17^{\circ} 21^{\prime} 14^{\prime \prime} \mathrm{E}$ & $1621 \mathrm{~m}$ \\
Secridata & $20^{\circ} 21^{\prime} 66^{\prime \prime} \mathrm{S}$ & $17^{\circ} 22^{\prime} 86 " \mathrm{E}$ & $1598 \mathrm{~m}$ \\
Elandsdrink & $20^{\circ} 19^{\prime} 22^{\prime \prime} \mathrm{S}$ & $17^{\circ} 22^{\prime} 54^{\prime \prime} \mathrm{E}$ & $1621 \mathrm{~m}$ \\
Kiewit & $20^{\circ} 18^{\prime} 50^{\prime \prime} \mathrm{S}$ & $17^{\circ} 19^{\prime} 37^{\prime \prime} \mathrm{E}$ & $1647 \mathrm{~m}$ \\
Duitsepos & $20^{\circ} 23^{\prime} 57^{\prime \prime} \mathrm{S}$ & $17^{\circ} 18^{\prime} 16^{\prime \prime} \mathrm{E}$ & $1624 \mathrm{~m}$ \\
Huilboom & $20^{\circ} 25^{\prime} 47^{\prime \prime} \mathrm{S}$ & $17^{\circ} 15^{\prime} 69^{\prime \prime} \mathrm{E}$ & $1664 \mathrm{~m}$ \\
Geelhout & $20^{\circ} 28^{\prime} 56^{\prime \prime} \mathrm{S}$ & $17^{\circ} 14^{\prime} 64^{\prime \prime} \mathrm{E}$ & $1655 \mathrm{~m}$ \\
\hline
\end{tabular}




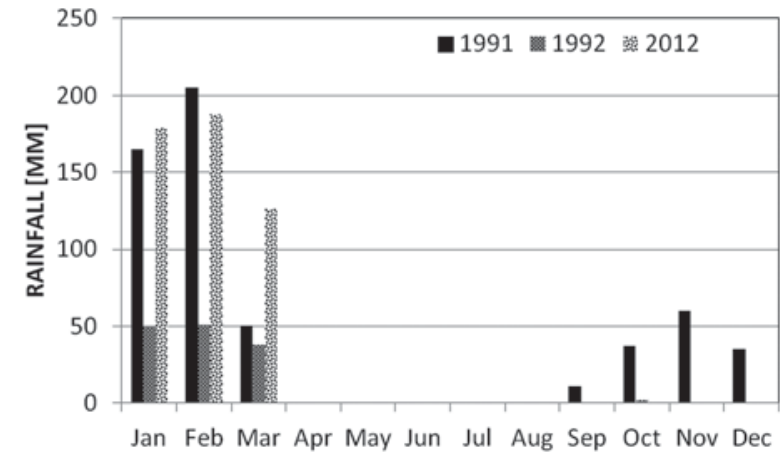

Fig. 2. Monthly rainfall at Otjiwarongo in the years of study (data from (http://www.meteona.com/index.php/climate/seasonal).

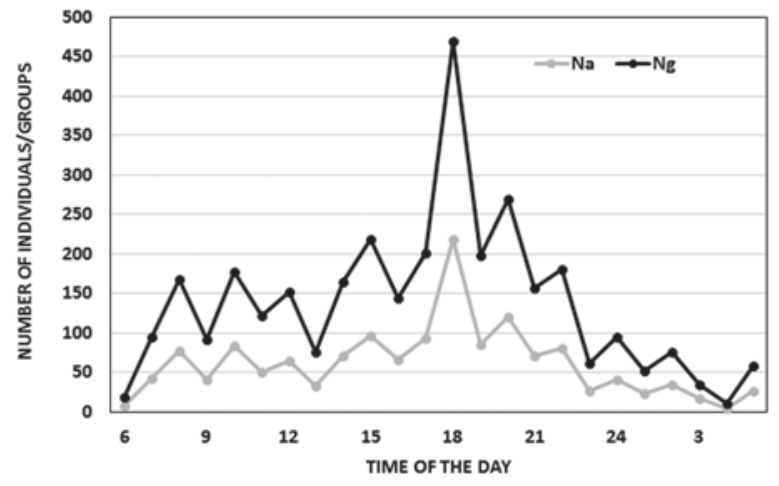

Fig. 3. General daily drinking activity pattern of all ungulates in the dry season in the Waterberg National Park. $\mathrm{Na}-$ number of individuals, $\mathrm{Ng}$ - number of groups.

Table 2. Sunrise and sunset time at Waterberg National Park in the month of study (data from https// www.timeanddate.com/sun/namibia).

\begin{tabular}{|l|c|c|c|}
\hline \multicolumn{1}{|c|}{ Date } & Sunrise & Sunset & Day length \\
\hline 1st June 1991 & $07: 16$ & $18: 14$ & $10: 57: 34$ \\
\hline 15th June 1991 & $07: 21$ & $18: 14$ & $10: 53: 05$ \\
\hline 30th June 1991 & $07: 24$ & $18: 18$ & $10: 53: 28$ \\
\hline 1st August 1992 & $07: 18$ & $18: 30$ & $11: 11: 28$ \\
\hline 15th August 1992 & $07: 10$ & $18: 34$ & $11: 24: 21$ \\
\hline 31th August 1992 & $06: 57$ & $18: 38$ & $11: 41: 15$ \\
\hline 1st July 2012 & $06: 24$ & $17: 18$ & $10: 53: 55$ \\
\hline 15th July 2012 & $06: 24$ & $17: 23$ & $10: 59: 38$ \\
\hline 31st July 2012 & $06: 19$ & $17: 29$ & $11: 10: 47$ \\
\hline
\end{tabular}

than once to the water point. Animals were counted separately in each group.

Since no year-to-year variations in the drinking activity were detected, the data from 1991, 1992 and 2012 were pooled and presented on graphs as from $6 \mathrm{~h} 00$ to $6 \mathrm{~h} 00$ of the following day. The $\chi^{2}$-test was used to test the differences in activity between day (6h00 18h00) and night (18h00-6h00) and between the first half $(18 \mathrm{~h} 00-24 \mathrm{~h} 00)$ and the second half of the night (24h00-6h00). Both number of animal groups and number of individuals were considered in the tests. The time of the sunrise and sunset in the month of study are presented in Table 2 .

\section{Results}

All 12 ungulate species occurring in the WNP utilized water holes on a daily basis. During five day-andnight observations (24 hours), a total of 3519 animals were recorded. In addition to this number, animals from other orders were also recorded as utilizing water hole on a few occasions: springhare Pedetes capensis $(n=1)$, scrub hare Lepus saxatilis $(n=2)$, Cape porcupine Hystrix africaeaustralis $(n=3)$, African wild cat Felis sylvestris lybica $(n=1)$, black-backed jackal Canis mesomelas $(n=6)$, bat-eared fox Otocyon megalotis $(n=6)$, honey badger Mellivora capensis $(n=4)$, brown hyaena Parahyaena brunnea $(n=2)$, and Chacma baboon Papio ursinus $(n=200)$ were relatively common at water holes. On the other hand, large carnivores, such as leopard and cheetah were recorded only on 1-2 occasions.

Drinking by ungulates was more frequent between $15 \mathrm{~h} 00$ and $22 \mathrm{~h} 00$ ( 7 hours) than in the rest of the day (24 hours). More than half of all individuals and groups were recorded during this time (Fig. 3). A conspicuous peak in drinking activity occurred in the evening between $18 \mathrm{~h} 00$ and $19 \mathrm{~h} 00$, when $15 \%$ of animals were recorded drinking water (Fig. 3).

Water holes had various frequency of attendance by particular ungulate species. In one day ( 24 hours) the number of animals at a given water hole varied from 123 to 438 (mean=373; SD=117.8; $n=7$ ). The differences were caused mainly by the buffalo and eland, which were the most frequently recorded species at water holes, comprising together almost half of all ungulates recorded.

The kudu, roan, sable antelope and warthog were also in the group of water-dependent species (comprising together $41.2 \%$ of all animals recorded at water holes). All other ungulate species attended the water holes with lower frequencies (Figs 4-6). 

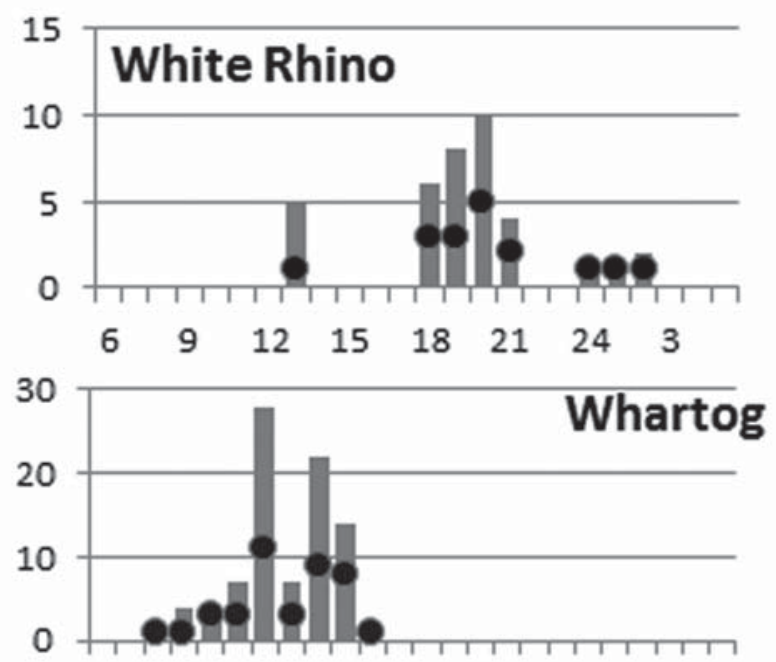

$\begin{array}{llllllll}6 & 9 & 12 & 15 & 18 & 21 & 24 & 3\end{array}$
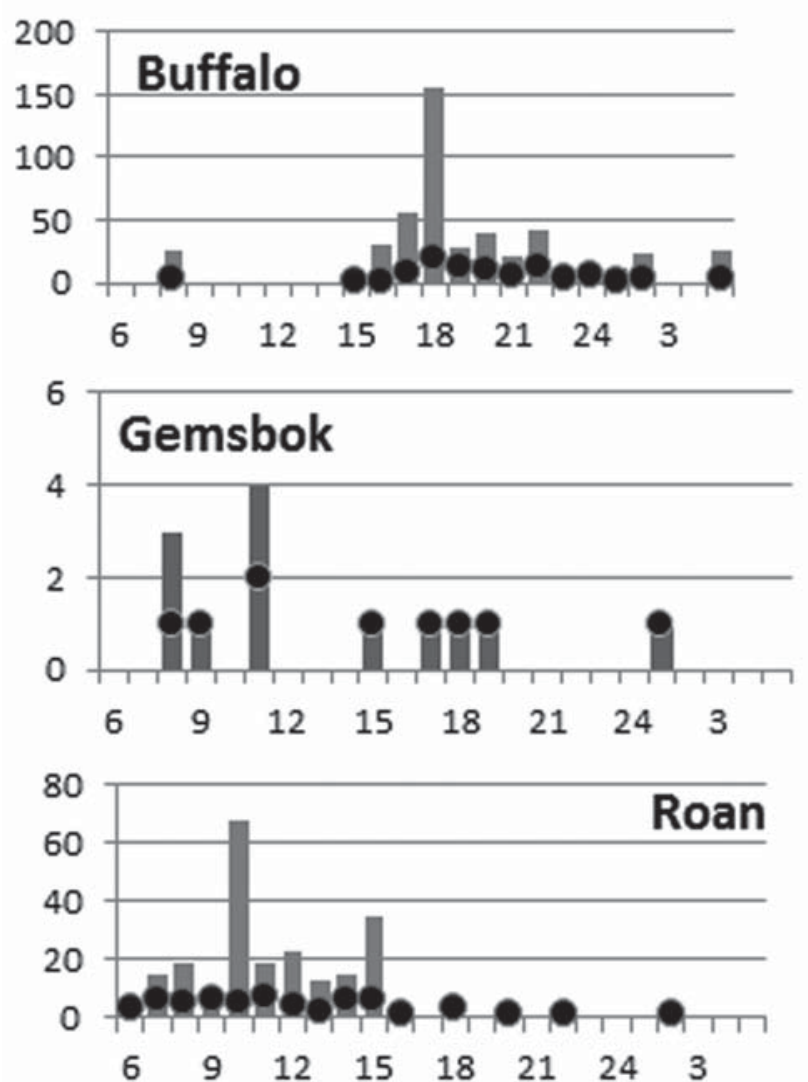
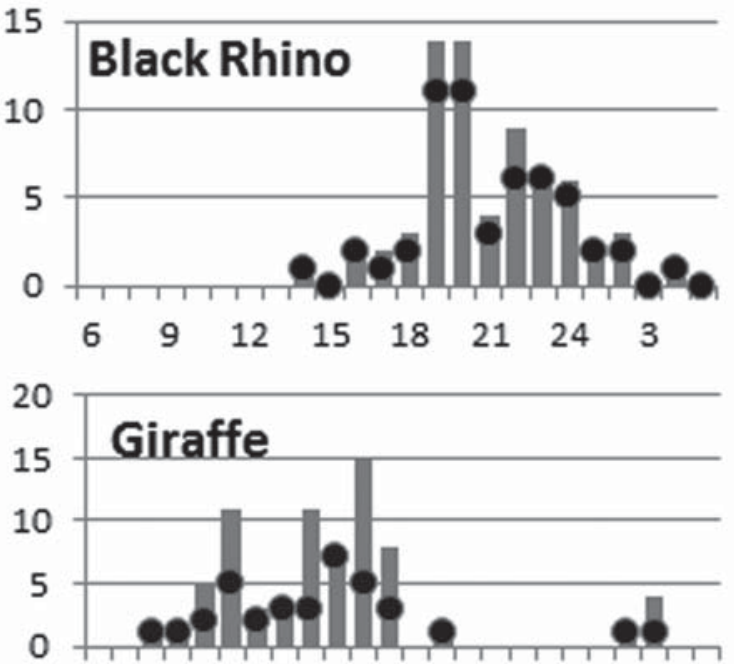

$\begin{array}{llllllll}6 & 9 & 12 & 15 & 18 & 21 & 24 & 3\end{array}$



$\begin{array}{llllllll}6 & 9 & 12 & 15 & 18 & 21 & 24 & 3\end{array}$
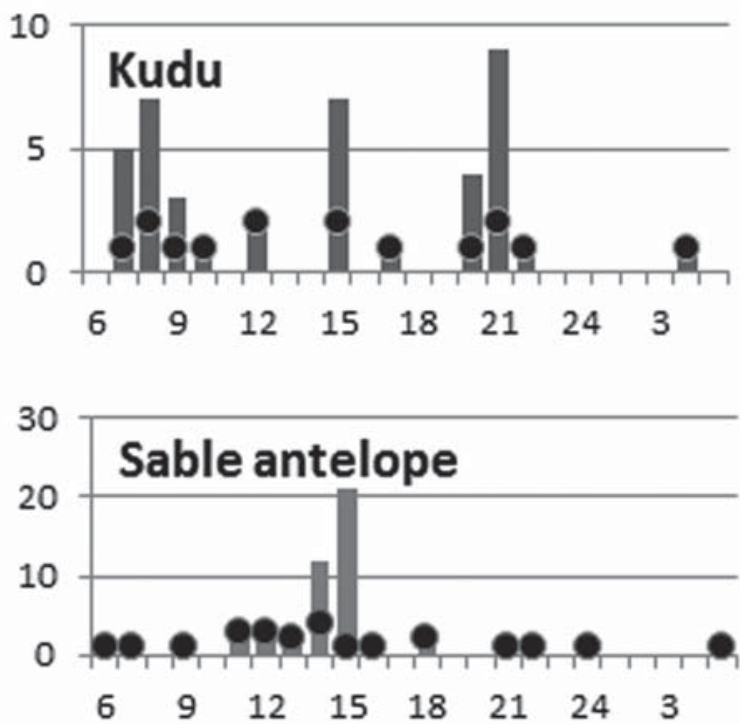

Fig. 4. Daily drinking activity pattern of particular ungulate species in the dry season in the Waterberg National Park. Columns — number of individuals, dots — number of groups; $x$-axis — number of individuals/groups; $y$-axis — the time of the day.

White rhino, black rhino and buffalo drank mainly between $18 \mathrm{~h} 00$ and 24h00; eland between $18 \mathrm{~h} 00$ and $24 \mathrm{~h} 00$ and $6 \mathrm{~h} 00$ and $9 \mathrm{~h} 00$; warthog and giraffe mostly between $11 \mathrm{~h} 00$ and 15h00; while kudu throughout the day and evening. Sable antelope and roan were found at water holes mainly between $7 \mathrm{~h} 00$ and $15 \mathrm{~h} 00$ (Fig. 4).
Only the warthog was exclusively diurnal in its drinking activity. Mostly diurnal were roan, sable antelope, giraffe and red hartebeest (Fig. 5), and mostly nocturnal were buffalo, black rhino and white rhino. The eland was equally diurnal and nocturnal. Other ungulate species were mainly diurnal (Fig. 5). The differ- 


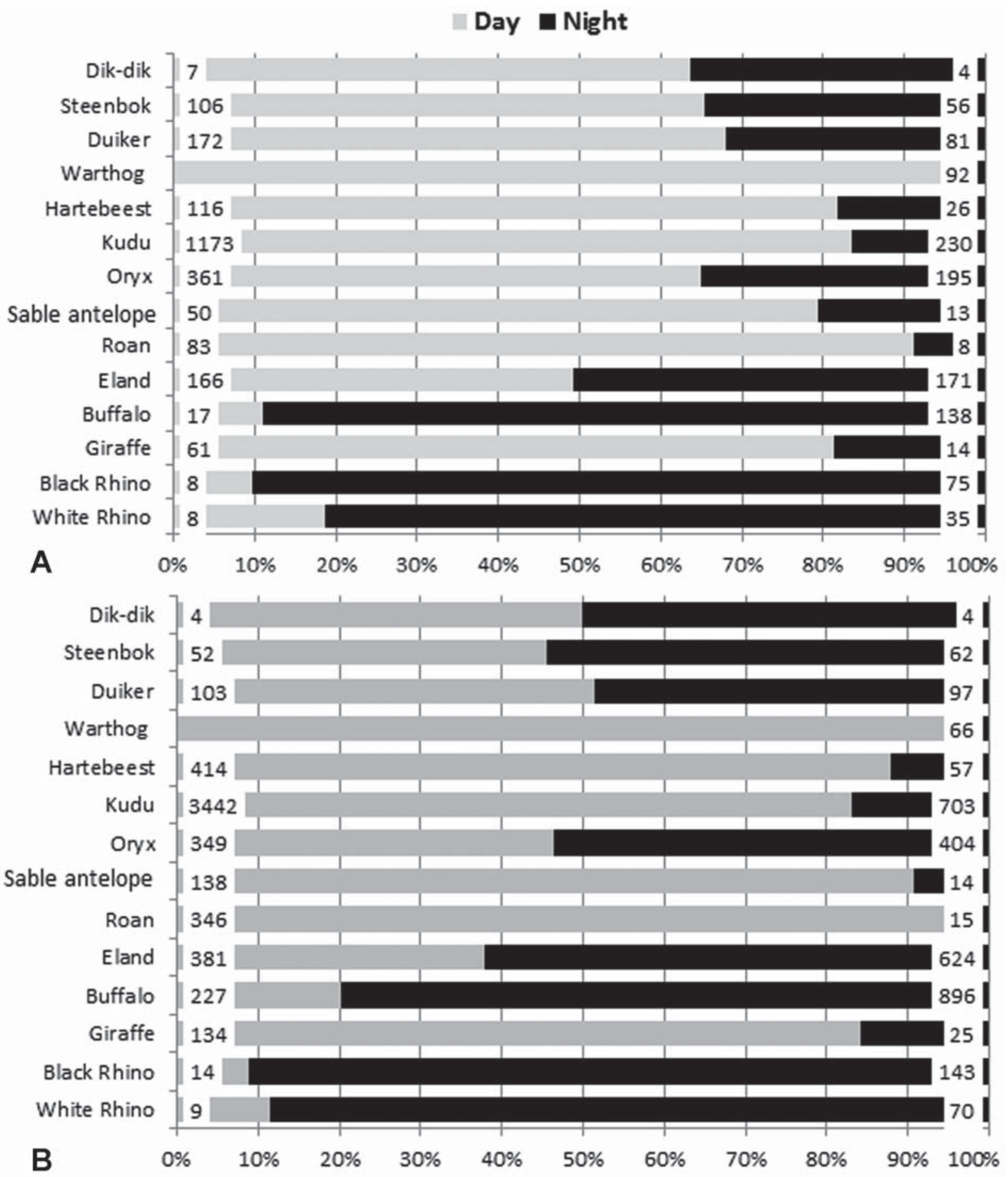

Fig. 5. A - proportions (in \%) of individuals of particular ungulate species visiting waterholes in the day and in the night in the dry season in the Waterberg National Park. At the extreme of each bars the total number of individuals is given. B proportions (in \%) of groups of particular ungulate species visiting waterholes in the day (6h00-18h00) and in the night $(18 \mathrm{~h} 00-6 \mathrm{~h} 00)$ in the dry season in the Waterberg National Park. At the extreme of each bars the total number of groups is given. 
Table 3. Statistical analysis between daily and nocturnal drinking activity, and between such activity in the first (18h00$24 \mathrm{~h} 00)$ and second (24h00-6h00) half of the night. Degree of freedom $=1 . \mathrm{E}<5$ - expected value lower than 5.

\begin{tabular}{|l|c|c|c|c|c|c|c|c|}
\hline \multirow{3}{*}{ Ungulate species } & \multicolumn{4}{|c|}{ Difference between day and night } & \multicolumn{3}{c|}{$\begin{array}{c}\text { Difference between the first and the } \\
\text { second half of the night }\end{array}$} \\
\cline { 2 - 11 } & \multicolumn{2}{|c|}{ groups } & \multicolumn{2}{c|}{ individuals } & \multicolumn{2}{c|}{ groups } & \multicolumn{2}{c|}{ individuals } \\
\cline { 2 - 10 } & $\chi^{2}$ & $p$ & $\chi^{2}$ & $p$ & $\chi^{2}$ & $p$ & $\chi^{2}$ & $p$ \\
\hline White rhino & 17.0 & 0.01 & 47.1 & 0.01 & 15.1 & 0.01 & 44.8 & 0.01 \\
\hline Black rhino & 54.1 & 0.01 & 106.0 & 0.01 & 22.4 & 0.01 & 57.9 & 0.01 \\
\hline Giraffe & 29.5 & 0.01 & 74.7 & 0.01 & 1.1 & $>0.05$ & 3.2 & $>0.05$ \\
\hline Buffalo & 94.5 & 0.01 & 398.5 & 0.01 & 46.4 & 0.01 & 335.2 & 0.01 \\
\hline Eland & 0.1 & $>0.05$ & 58.8 & 0.01 & 52.8 & 0.01 & 333.2 & 0.01 \\
\hline Roan & 61.8 & 0.01 & 303.5 & 0.01 & $\mathrm{E}<5$ & & 3.3 & $>0.05$ \\
\hline Sable antelope & 21.7 & 0.01 & 101.2 & 0.01 & 0.1 & $>0.05$ & 0.3 & $>0.05$ \\
\hline Gemsbok & 49.6 & 0.01 & 4.0 & 0.05 & 61.1 & 0.01 & 154.7 & 0.01 \\
\hline Kudu & 633.8 & 0.01 & 1809.9 & 0.01 & 91.8 & 0.01 & 334.6 & 0.01 \\
\hline Red hartebeest & 57.0 & 0.01 & 270.6 & 0.01 & 3.8 & 0.05 & 11.0 & 0.01 \\
\hline Warthog & 32.7 & 0.01 & 0.2 & $>0.05$ & 34.7 & 0.01 & 38.4 & 0.01 \\
\hline Common duiker & 15.4 & 0.01 & $\mathrm{E}<5$ & & $\mathrm{E}<5$ & & $\mathrm{E}<5$ & \\
\hline
\end{tabular}

ence between diurnal and nocturnal activities, both in relation to the groups and individuals visiting the water holes, were statistically highly significant (Table 3 ).

Most animals drinking during the night were more active in the first half $(18 \mathrm{~h} 00-24 \mathrm{~h} 00)$ than in the second half (24h00-6h00) of the night (Fig. 6). Only four species, namely the steenbok, sable antelope, roan and giraffe were relatively active in the second half of the night (ca. 1/3 of night activity). These differences were statistically highly significant both in relation to groups and individuals (Table 3).

\section{Discussion}

The utilization of water by game differs from habitat to habitat, from month to month and from species to species (Cain et al., 2012; Crosmary at al., 2012; Hayward \& Hayward, 2012). The drier the habitat, the higher the water demand. An increase in salt and protein content of vegetation causes an increase in water intake (Bothma, 2002; Hayward \& Hayward, 2012). In the dry season, water intake from artificial holes is much higher than in the wet season (Cain et al., 2012; Hayward \& Hayward, 2012). The larger, the animal species the higher water intake (Hayward \& Hayward, 2012). Among herbivores, grazers demand more water than browsers, and young animals more than adults. Water intake also increases during pregnancy (Bothma, 2002). These variations may influence the daily drinking activity patterns.

This study was based on observations carried out only in the nights with full moon. This could possible biased the results, as moon cycle may affect the circadian pattern of some mammal species. It is known that as the moon becomes darker, or it is closer to the new phase, there is often a higher frequency of movement of some animal species (Cozzi et al., 2012; Pratas-Santia- go et al., 2016). This aspect of activity of African ungulates has been, however, neglected by researchers. It is possible that diurnal or crepuscular species become more nocturnal under full moon nights, while predators are possibly more active when it is new moon. This premise requires, however, detailed investigation.

Water requirements differ markedly from species to species, e.g. white rhino - 72 liters per day, giraffe 40 , black rhino - 35, buffalo - 31, eland -23 , roan 10 , sable antelope, gemsbok and warthog — 9 liters (Bothma, 2002). Drinking frequency, which is linked to the water requirement and drinking activity, differs from species to species, from habitat to habitat, and from month to month. It is also greatly influenced by distribution, and the number of water points. In dry season, ungulates drink water more frequently than in the wet season. If the water is freely accessible and evenly distributed, most ungulate species will drink at least once a day (Bothma, 2002; Cain et al., 2012; Crosmary et al., 2012; Hayward \& Hayward, 2012). For example the elephant in Etosha National Park, where water holes are evenly distributed and easily accessible, frequents water once a day (du Preez \& Grobler, 1977), in drier neighbouring Koakoland, where the water is not so freely available - every three days (Bothma, 2002), in Kruger National Park, South Africa, which is more humid than Etosha N.P., but where water is not so evenly distributed as in Etosha N.P., every second day (Bothma, 2002).

Four groups of ungulates may be distinguished in the WNP based on their daily drinking activity patters: 1) evening and night drinkers: white rhino, black rhino and buffalo; 2) night and morning drinkers: eland, gemsbok and kudu; 3) day drinkers: warthog, giraffe, roan, sable antelope, red hartebeest; and whole day and night drinkers: dik-dik, steenbok, common duiker. This grouping is interesting as it reflects to a large extend the risk 

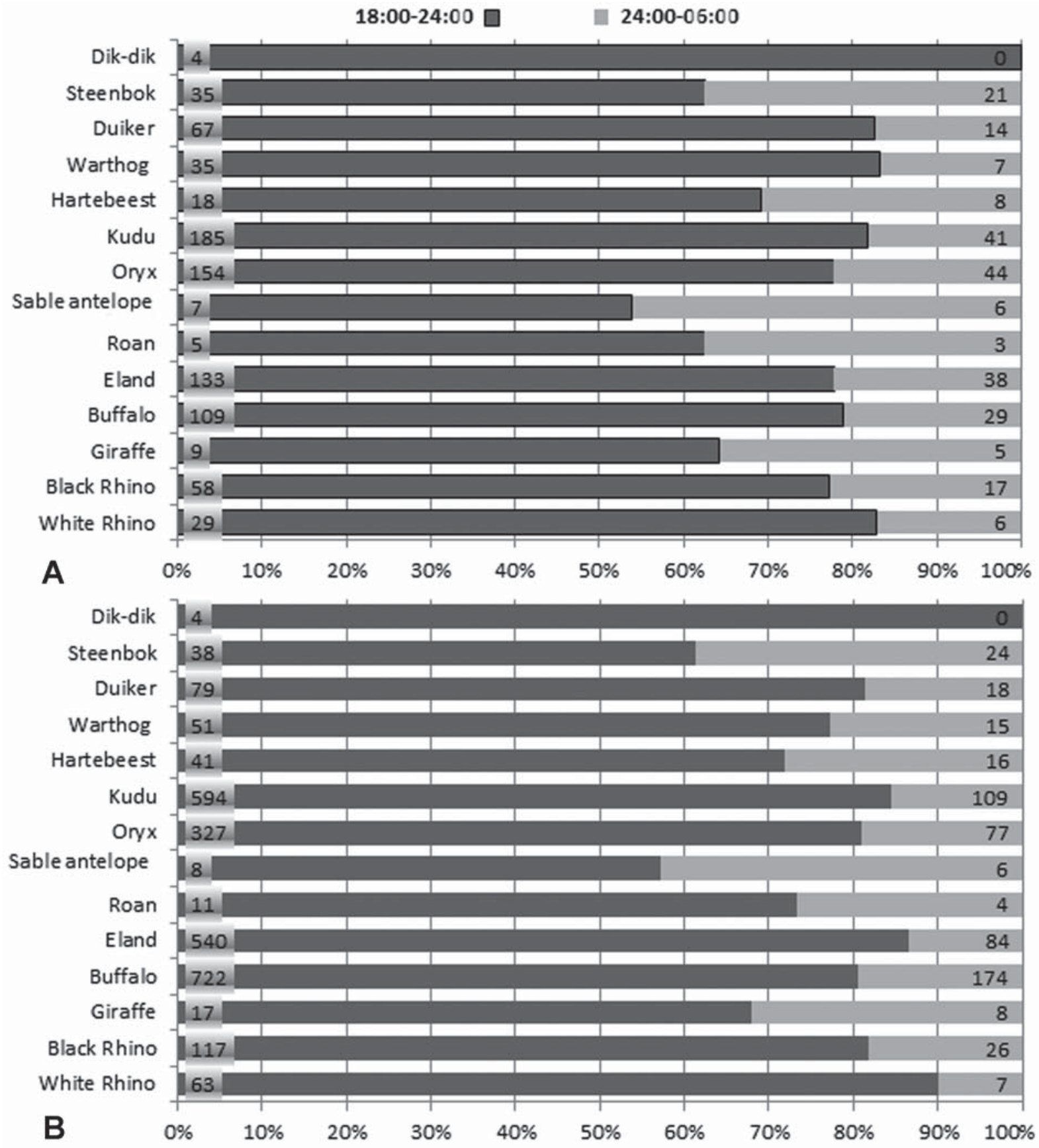

Fig. 6. A - proportions (in \%) of individuals of particular ungulate species visiting waterholes in the first (18h00-24h00) and in the second (24h00-6h00) half of the night in the dry season in the Waterberg National Park. At the extreme of each bars the total number of individuals is given. B - proportions (in \%) of groups of particular ungulate species visiting waterholes in the first (18h00-24h00) and in the second (24h00-6h00) half of the night in the dry season in the Waterberg National Park. At the extreme of each bars the total number of groups is given.

of ungulates to leopard predation. Since this risk is low in the case of large herbivores such as rhinos and buffalos, they are the only which have main drinking activity in the night when the leopard predation is the highest. The vulnerability to leopard predation is low in the case of large spiral-horned antelopes, such as the eland, gemsbok and kudu (Hayward et al., 2006; Hay- ward \& Kerley, 2008; Crosmary et al., 2012), and it is why they are active in drinking both in the night and in the morning. The giraffe, roan, sable antelope, red hartebeest, and warthog are vulnerable to leopard predation (Hayward et al., 2006; Hayward \& Kerley, 2008; Crosmary et al., 2012), and they are at water holes mostly in the day. The small antelopes, fall well within 
Table 4. Comparison of daily drinking activity of ungulates in three areas in Africa.

\begin{tabular}{|c|c|c|c|c|c|}
\hline \multirow{2}{*}{ Place } & \multicolumn{4}{|c|}{ Pattern of activity } & \multirow{2}{*}{ Source } \\
\hline & Evening/night & Night/morning & Day & Day/night & \\
\hline $\begin{array}{c}\text { Wankie N.P., } \\
\text { Zimbabwe }\end{array}$ & $\begin{array}{l}\text { buffalo, } \\
\text { giraffe, } \\
\text { zebra }\end{array}$ & $\begin{array}{l}\text { eland, } \\
\text { blue wildebeest }\end{array}$ & $\begin{array}{l}\text { warthog, } \\
\text { kudu, } \\
\text { sable antelope, } \\
\text { roan }\end{array}$ & & $\begin{array}{l}\text { Weir \& } \\
\text { Davisen, } \\
1960\end{array}$ \\
\hline $\begin{array}{l}\text { Etosha N.P., } \\
\text { Namibia }\end{array}$ & & $\begin{array}{l}\text { black rhino, white } \\
\text { rhino, } \\
\text { elephant }\end{array}$ & $\begin{array}{l}\text { warthog, } \\
\text { kudu, } \\
\text { gemsbok, } \\
\text { eland }\end{array}$ & giraffe & $\begin{array}{l}\text { du Preez \& } \\
\text { Grobler, } \\
1977\end{array}$ \\
\hline $\begin{array}{c}\text { Waterberg } \\
\text { N.P., Namibia }\end{array}$ & $\begin{array}{l}\text { black rhino, } \\
\text { white rhino, } \\
\text { buffalo }\end{array}$ & eland & $\begin{array}{l}\text { warthog, } \\
\text { giraffe, } \\
\text { sable antelope, } \\
\text { roan }\end{array}$ & kudu & this study \\
\hline
\end{tabular}

the preferred prey size of the leopard (Stander et al., 1997; Hayward \& Kerley, 2008). They were, therefore, expected to be mostly diurnal in their drinking activity, but at WNP they were in fact equally active in the day and night. The sample size for those species was, however, too meager to make a firm statement about their preferred time. They are also known to be quite independent of water in their territories (Kingdon, 1996).

The activity pattern of African ungulates at waterholes in dry seasons may be affected also by megaherbivores, such as elephant, white rhino, black rhino, buffalo, and eland. If those megaherbivores occur in a given area in larger numbers, then they tend to dominate at waterholes in the evening, between $18 \mathrm{~h} 00$ and 21h00. This appears to be most preferred time for drinking activities for most ungulates (Weir \& Davisen, 1960; du Preez \& Grobler, 1977; this study), but megaherbivores may easily compete with smaller species, eliminating them from waterholes in that time.

Night, especially the second half, is generally avoided by most herbivores (Weir \& Davisen, 1960; du Preez \& Grobler, 1977; Canda \& Cote, 2012; Hayward \& Hayward, 2012; this study). Large predators, such as the lion Panthera leo, leopard, and spotted hyaena are most active in that time, as has been shown by du Preez \& Grobler (1977) and by Hayward \& Hayward (2012). As anti-predator adaptation, medium-sized and small ungulates avoid drinking water at that time, even in the areas where their density of those predators is very low (e.g. in WNP). The Warthog was exclusively diurnal in drinking activity in all three study areas (Table 4). Among African ungulates, it is one of the most vulnerable species to large carnivore attacks.

The daily drinking activity patterns of ungulates in the WNP are quite different from those in Etosha N.P., but similar to those in Wankie N.P. In Etosha N.P. and WNP despite the relatively short distance between these areas, only the warthog shows the same activity pattern. On the other hand, there were five ungulate species with the same daily activity patterns in the WNP, and Wank- ie N.P., Etosha N.P. is an arid environment, while the vegetation in WNP and Wankie N.P. have similar structure of wet savanna and more humid climate. Probably, the density of large predators, such as lion, leopard, cheetah, hunting dog and spotted hyaena may play a role in this regard (Kanda \& Cote, 2012). Their densities are much higher in Etosha N.P. than in WNP.

Any disturbances at waterholes linked to their repair, reconstruction, enlargement etc. should be avoided in late afternoon and at evenings. In the dry season, they should take place, if possible, in the night, preferable in the second half of the night. On the other hand, tourists are encourage to visit specially constructed observatory points near the waterholes in late afternoon and evenings, but only in a way to avoid any disturbances of the game (Wakefield \& Attum, 2006).

ACKNOWLEDGEMENTS. We would like to express our gratitude to the referee, Dr. M.W. Hayward from Bangor University, UK, for his constructive comments on earlier draft of this paper. Our thanks are also due to Mr. H.B. Le Roux, Control Warden of Central Parks, Directorate of Wildlife and National Park, Ministry of Environment and Tourism, Mr. B.K. Kandjii, Chief Warden of Central Parks, and Mr. J.D. Masen, Warden of Waterberg National Park for providing us logistic support to this study. Mr. S. Dirkes from the Namibian Meteorological Service is thanked for providing the rainfall data. The study was financed through the Namibia Students Financial Assistance Fund (NSFAF).

\section{References}

Aschoff X. 1964. Survival value of diurnal rhythms // Symposia of the Zoological Society London. Vol.13. P.79-89.

Bothma J. du P. (ed.). 2002. Game ranch management. Pretoria: Van Schaik Publishers. 709 p.

Cain J.W., Owen-Smith N. \& Macandza V.A. 2012. The cost of drinking: Comparative water dependency of sable 
antelope and zebra // Journal of Zoology. Vol.286. P.5867.

Cozzi G., Broekhius F., McNutt J.W., Turnbull L.A., Macdonald D.W. \& Schmid B. 2012. Fear of the dark or dinner by moonlight? Reduced temporal partitioning among Africa's large carnivores // Ecology. Vol.93. P.2590-2599.

Crosmary W.-G., Valeix M., Fritz H., Madzikanda H. \& Côte S.D. 2012. African ungulates and their drinking problems: hunting and predation constrain access to water // Animal Behaviour. Vol.83. P.145-153.

du Preez J.S. \& Grobler D. 1977. Drinking times and behavior at waterholes of some game species in the Etosha National Park // Madoqua. Vol.10. P.61-69.

du Toit J.T. \& Yetman C.A. 2005. Effect of body size on the diurnal activity budgets of African browsing ruminants // Oecologia. Vol.143. P.317-325.

Hayward M.W., Henschel P., O’Brien J., Hofmeyr M., Balme G. \& Kerley G.I.H. 2006. Prey preferences of the leopard (Panthera pardus) // Journal of Zoology. Vol.270. P.298313.

Hayward M.W. \& Hayward M.D. 2012 Waterhole use by African fauna // South African Journal of Wildlife Research. Vol.42. P.117-127.

Hayward M.W. \& Kerley G.I.H. 2008. Prey preferences and dietary overlap amongst Africa's large predators // South African Journal of Wildlife Research. Vol.38. P. 93108.

Jankowitz W.J. 1983. Die plantekologie van die Waterberg Platopark. Dr. Sci. Thesis. Bloemfontein: University of the Orange Free State.

Jankowitz W.J. \& Venter H.J.T. 1987. Die plantgemeenskappe van die Waterberg-platopark // Madoqua. Vol.15. P.97-146.

Kanda H. \& Cote S.D. 2012. African ungulates and their drinking problems: hunting and predation risks constrain access to water // Animal Behaviour. Vol.83. P.145-153.

Kingdon J. 1997. The Kingdon field guide to African mammals. London: Academic Press. 465 p.

Mendelsohn J., Jarvis A., Roberts C. \& Robertson T. 2009. Atlas of Namibia. A portrait of land and its people. Cape Town: Sunbird Publishers. 200 p.
Pratas-Santiago L.P., Gonçales A.L.S., da Maria Soares A.M.V. \& Spironello W.R. 2016. The moon cycle effect on the activity pattern of ocelots and their prey // Journal of Zoology. Vol.299. P.275-283.

Regassa R. 2014. Diurnal activity pattern of Burchell's zebra (Equus burchelli Grey, 1824) in Yabello Wildlife Sanctuary, Southern Ethiopia // International Journal of Current Research in Bioscience \& Plant Biology. Vol.1. P.70-78.

Ryan S.J. \& Jordaan W. 2005. Activity patterns of African buffalo Syncerus caffer in the Lower Sabie Region, Kruger National Park, South Africa // Koedoe. Vol.8. P.117124.

Stander P.E., Haden P.J., Kaqece \& Ghau. 1997. The ecology of asociality of Namibian leopards // Journal of Zoology. Vol.242. P.343-364.

Stein A.B., Fuller T.K., De Stefano S. \& Marker L.L. 2011. Leopard population and home range estimates in northcentral Namibia // African Journal of Ecology. Vol.49. P.383-387.

Tahani A.H. \& Ibrahim M.H. 2014. Diurnal activity of waterbuck (Kobus ellipsiprymnus defassa) in Dinder National Park, Sudan // Journal of Nature Research \& Environmental Studies. Vol.2. P.15-19.

Tekaling W. \& Bekele A. 2015. Diurnal activity pattern of oribi (Ourebia ourebi) in Maze National Park, Ethiopia // International Journal of Ecology \& Ecosolution. Vol.2. No.3. P.31-35.

Thrash I. 1998. Impact of water provision on herbaceous vegetation in Kruger National Park, South Africa // Journal of Arid Environment. Vol.38. P.437-450.

Wakefield D.S. \& Attum O. 2006. The effect of human visits on the use of waterhole by endangered ungulates // Journal of Arid Environment. Vol.65. P.668-672.

Weir J. \& Davisen E. 1960. Daily occurrence of African game animals at water holes during dry season // African Zoology. Vol.1. P.353-368.

Western D. 1975. Water availability and its influence on the structure and dynamics of a savannah large mammal community // East African Wildlife Journal. Vol.13. P.265-286.

Winterbach H.E.K. \& Bothma J. du P. 1998. Activity patterns of the Cape buffalo Syncerus caffer caffer in the Willem Pretorius Game Reserve, Free State // South African Journal of Wildlife Research. Vol.28. P.73-80. 